\title{
Long-term records of glacier surface velocities in the Ötztal Alps (Austria)
}

\author{
Martin Stocker-Waldhuber ${ }^{1,2}$, Andrea Fischer ${ }^{1}$, Kay Helfricht ${ }^{1}$, and Michael Kuhn ${ }^{3}$ \\ ${ }^{1}$ Institute for Interdisciplinary Mountain Research, Austrian Academy of Sciences, 6020 Innsbruck, Austria \\ ${ }^{2}$ Department of Geography, Physical Geography, Catholic University of Eichstätt-Ingolstadt, 85072 Eichstätt, \\ Germany \\ ${ }^{3}$ Institute of Atmospheric and Cryospheric Sciences, University of Innsbruck, 6020 Innsbruck, Austria \\ Correspondence: Martin Stocker-Waldhuber (martin.stocker-waldhuber@oeaw.ac.at)
}

Received: 4 December 2018 - Discussion started: 8 January 2019

Revised: 26 April 2019 - Accepted: 6 May 2019 - Published: 22 May 2019

\begin{abstract}
Climatic forcing affects glacier mass balance, which causes changes in ice flow dynamics and glacier length changes on different timescales. Mass balance and length changes are operationally used for glacier monitoring, whereas only a few time series of glacier dynamics have been recorded. Here we present a unique dataset of yearly averaged ice flow velocity measurements at stakes and stone lines covering more than 100 years on Hintereisferner and more than 50 years on Kesselwandferner. Moreover, the dataset contains sub-seasonal variations in ice flow from Gepatschferner and Taschachferner covering almost 10 years. The ice flow velocities on Hintereisferner and (especially) on Kesselwandferner show great variation between advancing and retreating periods, with magnitudes increasing from the stakes at higher elevations to the lower-elevated stakes, making ice flow records at ablation stakes a very sensitive indicator of glacier state. Since the end of the latest glacier advances from the 1970s to the 1980s, the ice flow velocities have decreased continuously, a strong indicator of the negative mass balances of the glaciers in recent decades. The velocity datasets of the four glaciers are available at https://doi.org/10.1594/PANGAEA.896741.
\end{abstract}

\section{Introduction}

The fluctuation of glaciers has become an icon of climate change, after Agassiz (1847) hypothesized the theory of ice ages, which was then confirmed by Penck and Brückner (1909) and further substantiated with isotope analysis on deep sea sediment and polar ice cores (Hays et al., 1976; Shackleton, 2000) and the theoretical work by Milankovitch (1920). First monitoring efforts focused on recording the changing positions of glacier termini, starting in the 17th century and systematically organized in the late 19th century, for example by the German and Austrian Alpine Club (Fritzsch, 1898; Groß, 2018). In the case of catastrophic glacier advances, as reported several times during the Little Ice Age, for instance, for Vernagtferner in the Ötztal Alps (Nicolussi, 2012), local observers often reported the velocity of terminus advances over short periods. At that stage of development, glaciological theory and monitoring techniques, the monitoring of horizontal ice flow velocities was already well established for Alpine glaciers. Stone line velocities were recorded at 5 glaciers among 20 glaciers regularly monitored for length changes in the Eastern Alps, for example, at the glaciers of Pasterze (Nicolussi and Patzelt, 2001), Vernagtferner (Braun et al., 2012) or Hintereisferner (Span et al., 1997), or in the Western Alps at Rhône Glacier (Mercanton, 1916; Roethlisberger, 1963) or Mer de Glace (Berthier and Vincent, 2012). At the glaciers Unteraargletscher and Mer de Glace, ice flow was already being measured during the 1840s (Forbes, 1846; Agassiz, 1847).

For Alpine glaciers, monitoring of velocity records received less attention after the turbulent decades of the First and Second World Wars. Development of glaciological programmes focused on hydrological programmes and mass balance programmes, as the understanding of glacier flow 
was advanced by deformation measurements on Hintereisferner and in the theoretical work of Finsterwalder (1907) and Hess (1924).

Estimates of the global glaciers' contribution to sea level rise is one of the urgent topics of research (e.g. Jacob et al., 2012; Zemp et al., 2019), and estimates of the state of regional glacier inventories are needed. Glacier flow velocities that can be derived from remote-sensing data are an important parameter that provides essential information on dynamic response, which is part of the mass balance evolution of a glacier. For example, ELA (equilibrium line altitude), which played a major role in large-scale data collections for global climate change, has been observed to be above summits and thus undefined for Eastern Alpine glaciers for much of the last decade (WGMS, 2017).

In this paper, two long-term series and two series of about a decade of ice flow velocities are revisited and compared with classical in situ mass balance measurements (Hoinkes, 1970) and ALS (airborne laser scanning) data (Abermann et al., 2010). On these four glaciers, ice flow velocities are measured in situ at stone lines (horizontal velocities) or at stakes (3-D velocities). The stones and stakes are annually relocated to their original position. Long-term velocity data are recorded annually, shorter time series also reveal seasonal variabilities. The four glaciers are also part of a network of long-term measurements of glacier fluctuations (Groß, 2018); area and volume change have been recorded in inventories from the LIA (Little Ice Age) maximum onwards (Patzelt, 1980; Groß, 1987; Kuhn et al., 2012; Fischer et al., 2015).

This paper presents ice flow velocity records on wellinvestigated mountain glaciers and their relation to other in situ monitoring parameters. These data can be used for validation of numerical ice flow models and further research on ice flow velocity as a monitoring parameter and climate proxy on various scales.

\section{Glacier sites and data}

The ice flow velocities have been recorded on four of the largest glaciers in the Ötztal Alps (Austria). Hintereisferner (HEF), Kesselwandferner (KWF), Gepatschferner (GPF) and Taschachferner (TSF) are neighbouring glaciers (Fig. 1) differing in size, aspect and elevation range (Table 1).

HEF, a typical valley glacier, has a long tradition of hydrological, meteorological, geophysical and glaciological investigations (e.g. Blümcke und Hess, 1899; Förtsch and Vidal, 1956; Hoinkes and Steinacker, 1975; Kuhn et al., 1999; Fischer, 2010; Helfricht et al., 2014; Strasser et al., 2018). Ice flow velocities on HEF have been sporadically but almost annually measured at ablation stakes for more than 100 years at stone lines (Span et al., 1997). Line 3 on HEF is the oldest stone line, started in 1895 and lasted until 1985 when the glacier retreated upstream from the location of the profile.

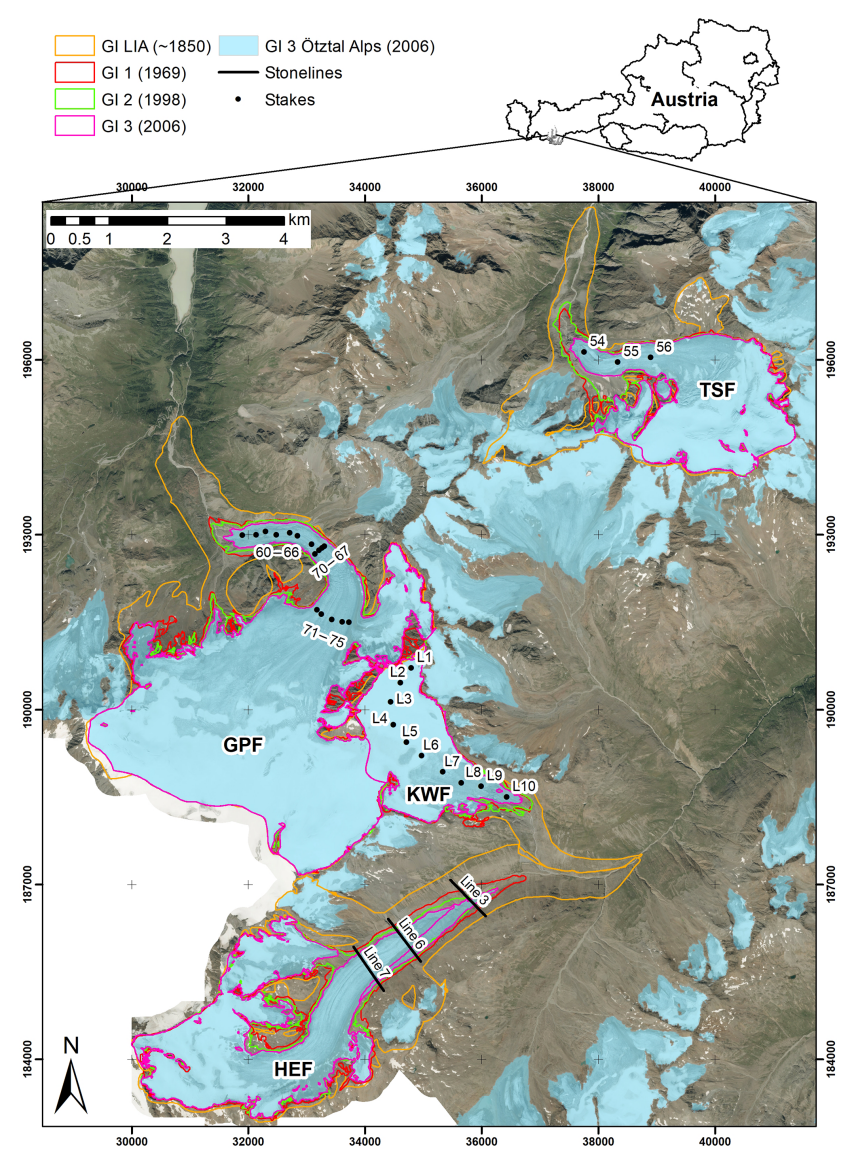

Figure 1. Location of the stone lines (3, 6 and 7) on Hintereisferner (HEF) and stakes on Kesselwandferner (KWF), Taschachferner (TSF) and Gepatschferner (GPF). On Gepatschferner, stakes 60 to 66 are longitudinal stakes from the glacier snout upwards to the first cross-profile including the stakes 67 to 70 (from the orographic right to the left). Stakes 71 to 75 are located in a cross-profile at the root zone of the tongue. The glacier area was taken from the Austrian Glacier Inventories (GI) from the LIA (Little Ice Age) around 1850, GI1 from 1969, GI2 from 1998 and GI3 from 2006 (Fischer et al., 2015). Background: orthophoto from 2015; data source: Land Tirol - https://www.tirol.gv.at/data/.

Records at Line 6 were started in 1932/33 and at Line 7 in 2013/14. In situ mass balances have been measured since 1952 (Hoinkes, 1970; Fischer, 2010; Fischer et al., 2013; Strasser et al., 2018).

The investigations on KWF are historically linked to those on HEF (e.g. Kuhn et al., 1985) with the same long-term investigations of length variations since 1884 and mass balances since 1952 (Fischer et al., 2014). The terminus of KWF detached from the tongue of HEF in 1914. KWF is a plateau glacier and covers a small elevation range compared to HEF, GPF and TSF, especially since the terminus retreated to the top of a steep terrain level and detached from the dead ice body at the front of this step in 2012. Velocity measurements were started in 1965 by Schneider (1970) at ablation 
Table 1. Geographic location and characteristic numbers of GPF, HEF, KWF and TSF from Austrian Glacier Inventory 3 of 2006 (Fischer et al., 2015) and the year of the start of velocity measurements (meas. since). exp: exposition; sc: accumulation area; sa: ablation area.

\begin{tabular}{llrrrrr}
\hline name & location & exp. sc & exp. sa & altitude range $[\mathrm{m}]$ & area $\left[\mathrm{km}^{2}\right]$ & meas. since \\
\hline GPF & $46.85^{\circ} \mathrm{N}, 10.75^{\circ} \mathrm{E}$ & $\mathrm{NE}$ & $\mathrm{N}$ & $2116-3501$ & 16.62 & $2009 / 10$ \\
$\mathrm{HEF}$ & $46.79^{\circ} \mathrm{N}, 10.75^{\circ} \mathrm{E}$ & $\mathrm{E}$ & $\mathrm{NE}$ & $2436-3715$ & 7.49 & $1894 / 95$ \\
$\mathrm{KWF}$ & $46.84^{\circ} \mathrm{N}, 10.79^{\circ} \mathrm{E}$ & $\mathrm{SE}$ & $\mathrm{E}$ & $2754-3496$ & 3.82 & $1965 / 66$ \\
$\mathrm{TSF}$ & $46.90^{\circ} \mathrm{N}, 10.86^{\circ} \mathrm{E}$ & $\mathrm{N}$ & $\mathrm{NW}$ & $2424-3756$ & 5.71 & $2009 / 10$ \\
\hline
\end{tabular}

stakes and at accumulation stakes along the centre flow line of the glacier. A comparison between direct glaciological and geodetic measurements on KWF, as well as on HEF, was presented by Fischer (2011). The main outcome of the comparison was that both mass balance datasets generally agree within measurement uncertainties.

GPF is the second largest glacier of the Austrian Alps. The main glacier rests on a wide but hilly plateau and the tongue descends through a narrow valley. After these early mappings (Sonklar, 1860; Finsterwalder, 1928), GPF was subject to geophysical investigations (Giese, 1963), photogrammetric analyses (Keutterling and Thomas, 2006) and is still one of the Eastern Alpine key research sites and has extensive knowledge on its Holocene fluctuations (Nicolussi and Patzelt, 2001). Recently, Gepatschferner became part of a detailed study on geomorphodynamics (Heckmann et al., 2012; Heckmann and Morche, 2019). In this study, the stake network at the glacier tongue was extended from 3 stakes, where velocities have been measured since 2009 , to 16 stakes in 2012. TSF is similar to GPF a plateau and valley glacier with a wide accumulation area and a narrow glacier tongue. The stake velocity records on TSF were started together with those on GPF in 2009 at three positions at the glacier tongue.

On both glaciers, GPF and TSF, the positions of the stakes are measured several times during the summer months, allowing a discussion of the sub-seasonal variability. In contrast, the velocity records at HEF and KWF were performed once a year and can be discussed in relation to their long-term mass balance records.

\section{Methods}

Based on the historical development of geodetic techniques, different methods came into operation on these glaciers during the past century. Trigonometric networks were installed in 1894 on HEF (Blümcke and Hess, 1899) and in 1965/66 on KWF (Schneider, 1970) to determine glacier surface velocities with a theodolite at stone lines on HEF and ablation stakes on both glaciers (Fig. 1). On HEF and KWF, stake velocities were measured using a theodolite and tachymeter until 2009. Since then DGPS (differential global positioning system) has been used. On GPF and TSF, the full series was measured by DGPS (system: Topcon; antennas: Hiper V; software: Magnet Tools).
The velocity records are compared to direct glaciological and geodetic mass balance measurements from Hoinkes (1970), Schneider (1970), Fischer (2010), Fischer et al. (2013), Stocker-Waldhuber et al. (2017) and Strasser et al. (2018) on HEF, KWF and GPF. In these publications, the surface mass balances were derived from stakes and snow pits by using the direct glaciological method (Hoinkes, 1970). Additionally, DEMs (digital elevation models) and DODs (DEMs of difference) from photogrammetric or highresolution ALS data came into operation to determine volume and elevation changes (Abermann et al., 2010).

\subsection{Velocity measurements at stone lines}

The method of stone lines (Heim, 1885; Hess, 1904) was only used on HEF at three cross-profiles. The position of several stones and their distance to each other is fixed within a defined cross-profile. The number of stones depends on the glacier width and thus varies in time with any expansion or reduction of the glacier. The position of the stones was measured initially with tachymetric systems and with DGPS since 2009. The stones are flat, with a diameter ranging from $0.15 \mathrm{~m}$ to a maximum of $0.3 \mathrm{~m}$. The distance between the original defined position of the stone within the profile and the position in the subsequent year is measured using a measuring tape. The horizontal displacement is calculated in consideration of the elevation change or the slope of the surface at each stone. The stones are then moved to their original position. From 2009, the displacement was calculated from the measured DGPS positions, but the measuring tape is still used for control. The annual velocities at the stone lines are given as the mean annual values of the stones in the profile and thus depend on the number of stones.

Velocity records from ablation stakes complemented earlier data for Line 6 (before 1932/33) and Line 7 (before 2013/14) for periods when the stakes were reinstalled at their original position. The stakes are located at the central flow line of the glacier, thus representing the maximum flow velocity at the profile. A ratio of $80 \%$ between the mean velocity from the stone line and the maximum velocity at stakes located at the centre of profile (Span and Kuhn, 2003) was taken to compare the stake values with the mean values from the stone lines. 


\subsection{Velocity measurements at stakes}

Velocity measurements are performed at ablation stakes and at accumulation stakes on KWF, GPF, and TSF and complement the stone lines on HEF. The position of the stakes and their motion on KWF is measured at the top of the stake and calculated to the lower end of the stake, its base point. This has the advantage that the measured velocity is not affected by surface changes of accumulation or ablation. Figure 2, taken from Schneider (1970), shows the components of the velocity vector $(\boldsymbol{d})$ at the base point of the stake within the accumulation area (left side) and the ablation area (right side) between two points in time (t1, t2) depending on submergence (negative value of $\boldsymbol{v}$ ) and emergence (positive value of $\boldsymbol{v})$. This definition coincides with the definition of submergence and emergence in Cogley et al. (2011). The vertical motion can be calculated as the remainder of the absolute elevation change of the surface $(\Delta d)$ and the accumulation or ablation $(\Delta a)$ from the elevation change due to the sloping surface $(\Delta h)$ and the vertical component $(\Delta z)$ of the velocity vector $(\boldsymbol{d})$ (Schneider, 1970). The difference between the actual flow path $(\boldsymbol{d})$, which is the length of the velocity vector, and the horizontal motion $(\Delta s)$, which is the projected velocity, results from the vertical component $(\Delta z)$. Annual values of the horizontal flow velocity $(\Delta s / a)$, as well as the vertical motion values of submergence and emergence, were calculated for $365 \mathrm{~d}$ and on the basis of a fixed coordinate system. The horizontal velocity component $(\Delta s)$ and the vertical component $(v)$ in Schneider (1970) correspond to the definitions of $(u)$ and $(w)$ in Cuffey and Paterson (2010). Upward motion is positive.

The stakes on KWF are reinstalled annually at their initial (xy) position. Redrilling and measurements are conducted with a level rod for exact perpendicular conditions. The reflector or the DGPS antenna is directly mounted to the top of the stake. Therefore, duraluminium stakes with a rigid connection are used on KWF as ablation stakes $(\varnothing=2 \mathrm{~cm})$ as well as thicker accumulation stakes with a diameter of $5 \mathrm{~cm}$ for the necessary resistance against snow pressure. Tipping over and melting in may lead to errors in measuring the vertical motion. On KWF, tipping over of the stakes is avoided by the use of duraluminium stakes. Wood wool underneath the stake and at the downhill side of the stake protects against melting.

\section{Accuracies and uncertainties}

The investigations on KWF are accurate to the low centimetre level $(0.05$ to $0.1 \mathrm{~m})$ for the horizontal and the vertical stake position determined with theodolite and tachymeter. This is possible because of statistical adjustment of the measured positions using resection and intersection techniques and especially the statistical adjustment of the trigonometric network. Further details of the derived errors for this specific dataset can be found in Schneider (1970). In 2009,
DGPS measurements with a RTK (real time kinematic) procedure came into operation. During these measurements, the base-station is located in close proximity to the glacier at fixed points of the trigonometric network (Schneider, 1970; Niederwald, 2009; Weide, 2009; Zauner, 2010), allowing a staking out of the stake position with a comparable accuracy in the low centimetre level. The overall accuracies depend on a proper implementation of the measurement methods. The precision requirements on KWF are in the range of $\pm 0.05 \mathrm{~m}$ per single measurement or at least $\pm 0.1 \mathrm{~m}$ for the period between the two readings for the horizontal and the vertical displacement.

In contrast to the stakes on KWF, ice flow velocities at GPF and TSF are measured at wooden ablation stakes with DGPS and a post-processing procedure, the measured positions refer to the glacier surface. The minimum occupation time for DGPS with post-processing is $10 \mathrm{~min}$ but is mostly in the range of 30 to $60 \mathrm{~min}$. The nearest base station, which provides basic data within the GPS and GLONASS satellite system, is located in Malles (STPOS-MABZ, $46^{\circ} 41^{\prime} 9.55^{\prime \prime} \mathrm{N}$, $10^{\circ} 33^{\prime} 3.73^{\prime \prime} \mathrm{E}$, South Tyrol, Italy). The baseline to the stakes on GPF is about $26 \mathrm{~km}$ and about $32 \mathrm{~km}$ to the stakes on TSF. The accuracies from the post-processing procedure on these glaciers are $\pm 0.1 \mathrm{~m}$ per single measurement or $\pm 0.2 \mathrm{~m}$ for the period between two readings at best. Additionally, the distance to the base station and shading effects of the surrounding topography lead to higher uncertainties for the DGPS measurements in the low decimetre to metre level.

The uncertainty of the stone line measurements on HEF, determined with a measuring tape, can only be estimated. They depend on the measuring distance, surface roughness and possible slipping of stones on the ice surface. The number of stones in the profile varies in time, which leads to a systematic error in the mean velocity of the lines. The number of stones at Line 7 decreased from 19 stones initially to 17 stones and at Line 6 to 4 stones in 2017. The velocities of the stone lines refer to the horizontal component of the velocity vector $(\Delta s)$ and are calculated from theodolite and tachymeter measurements until 2009 and with RTK-DGPS since then with an absolute error of $\pm 0.05 \mathrm{~m}$ per single measurement. An estimated uncertainty of the mean stone line velocity of $5 \%$ of the annual displacement is higher in contrast to the measurements on KWF due to the possible slipping motion of stones in the profile. The slipping error mainly depends more on the surface slope and the annual surface ablation than on the surface velocity. This means that the higher the ablation rate and the steeper the surface slope, the higher the slipping error. Consequently, this error becomes more important at low velocities (Blümcke and Finsterwalder, 1905). 

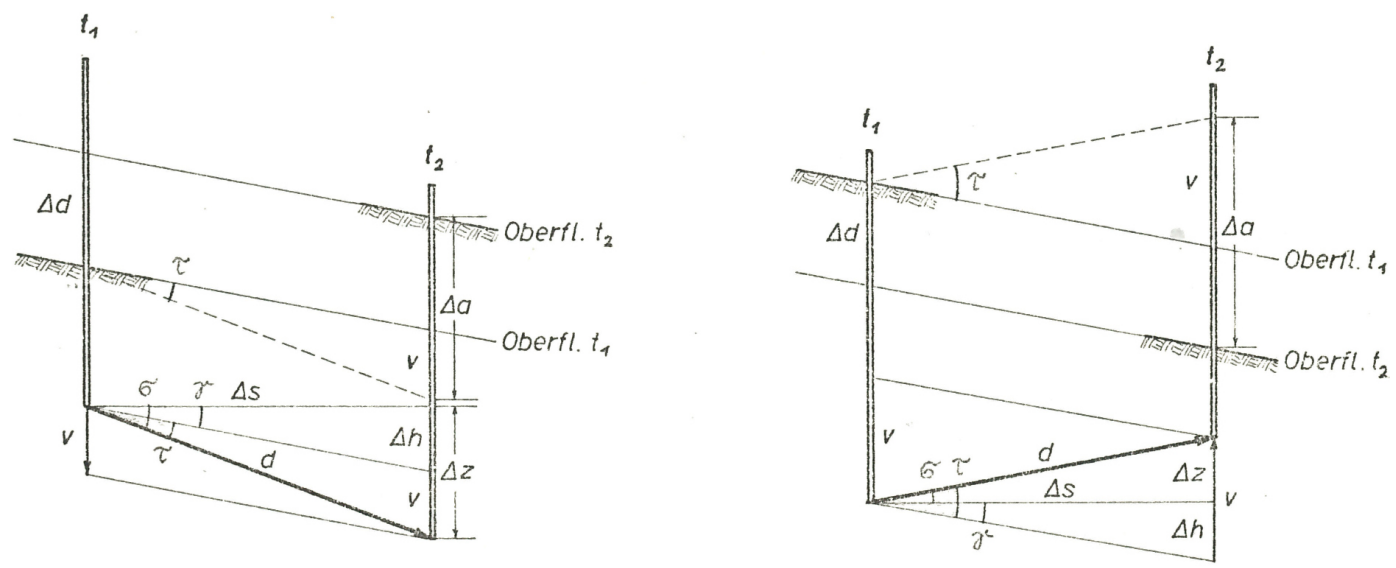

Figure 2. Drawings by Schneider (1970) of the motion of a stake and changes at the glacier surface (Oberfl.) between two time steps (t1, t2) within the accumulation area (left) and the ablation area (right). $\boldsymbol{d}$ : flow path (length of the velocity vector); $\boldsymbol{v}$ : vertical velocity; $\Delta s$ : horizontal velocity (projected velocity); $\Delta d$ : absolute surface elevation change; $\Delta a$ : point mass balance (relative surface elevation change from accumulation or ablation).

\section{Results}

\subsection{Hintereisferner}

Three stone line records on HEF display the variation in glacier surface velocities for different periods, for more than 100 years in total (Fig. 3). Three periods with increasing surface velocities were recorded on HEF. The first and most extensive acceleration of surface velocity happened before 1920 , with a maximum mean stone line velocity of $125 \mathrm{~m}$ per year at Line 3 in 1919 (Hess, 1924). This is $112 \mathrm{~m}$ per year above the mean flow velocity of $13 \mathrm{~m}$ per year of the long-term average (1895-1985) at this location. The velocity increased to this maximum within a few years and decreased very quickly until 1922, resulting in a small advance of the glacier terminus in subsequent years of around $60 \mathrm{~m}$ (Span et al., 1997). The second period was recorded from 1935 to the early 1940s and the most recent one during the 1970s. During that time, the mass balance of the glacier was positive for several years (Fig. 3). Since 1980, surface velocities on HEF have continuously decreased at the stone lines to about $4 \mathrm{~m}$ per year in recent years at Line 6 and to about $7-8 \mathrm{~m}$ per year at Line 7 . This continuous decrease is accompanied by strong negative mass balances in recent decades.

\subsection{Kesselwandferner}

On KWF, measurements were started in the hydrological year 1965/66, including horizontal and vertical ice flow velocities (Fig. 4 and Fig. 5). These long-term investigations document different glacier states at a longitudinal profile of up to 10 accumulation and ablation stakes. There are two main contrasting periods, the first period from the start of the measurements to 1985 and the second period since then. During the first period, the glacier advanced because of positive mass balances. During that time $75 \%$ of the measured glaciers in Austria and Switzerland advanced due to positive mass balances as a result of decreasing summer temperatures and increasing annual precipitation (Patzelt, 1985). The surface velocity of the glacier increased but with decreasing magnitudes from the terminus (L10) to the uppermost stake (L1) within the accumulation area. This means an increased velocity gradient along the glacier, with maximum of about $90 \mathrm{~m}$ per year at the terminus declining to a few metres per year at the highest elevations. The gradient of the vertical velocities was also large, with a submergence of up to $3 \mathrm{~m}$ per year within the accumulation zone to an emergence of up to $5 \mathrm{~m}$ per year at the lowermost stake. During that time the ELA (equilibrium line altitude) shifted to lower elevations, which can be seen as the transition from submergence to emergence from stake to stake.

The advancing state of the glacier ended in 1985, followed by a sharp decrease in the surface velocities and a reduction of the velocity gradients along the flow line. The terminus velocity response was large due to the positive mass balances. A significant change in velocity near the ELA at L6 did not occur until negative mass balances occurred around 1985. Submergence transitioned gradually to emergence around 1990 at stakes L8 and L7 and in 2005 at L6, representing a shift of the ELA to higher elevations. During that time, ELA shifted from $3130 \mathrm{~m}$ (mean value from 1985 to 1990) to $3214 \mathrm{~m}$ during the period 2005-2010, and even above the crest level in 2003 for the first time since the beginning of the mass balance measurements (Fischer et al., 2014; Strasser et al., 2018). At the lowermost stake L10, velocity decreased rapidly to almost zero because of the decreasing mass supply to the terminus. This area became ice free in 2010 (Figs. 4 and 5). The latest positive mass balance occurred in 2015, with an immediate response in the horizontal and vertical velocities. 


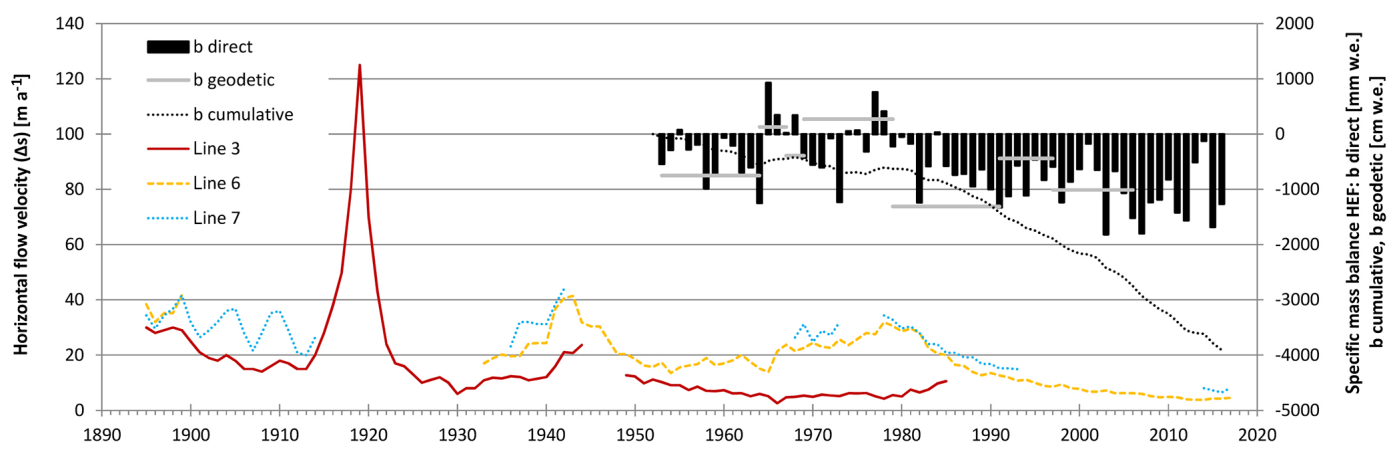

Figure 3. The mean annual velocities of the stones at lines 3, 6 and 7 on Hintereisferner since 1894/95 (=1895). The data series has been extended since Span et al. (1997) and annual specific surface mass balance (b direct) (Strasser et al., 2018; WGMS, 2017; original data: Hess, 1924), as well as the geodetic balances from DODs (b geodetic) by Fischer (2011) since 1953. Locations of the stone lines are shown in Fig. 1.

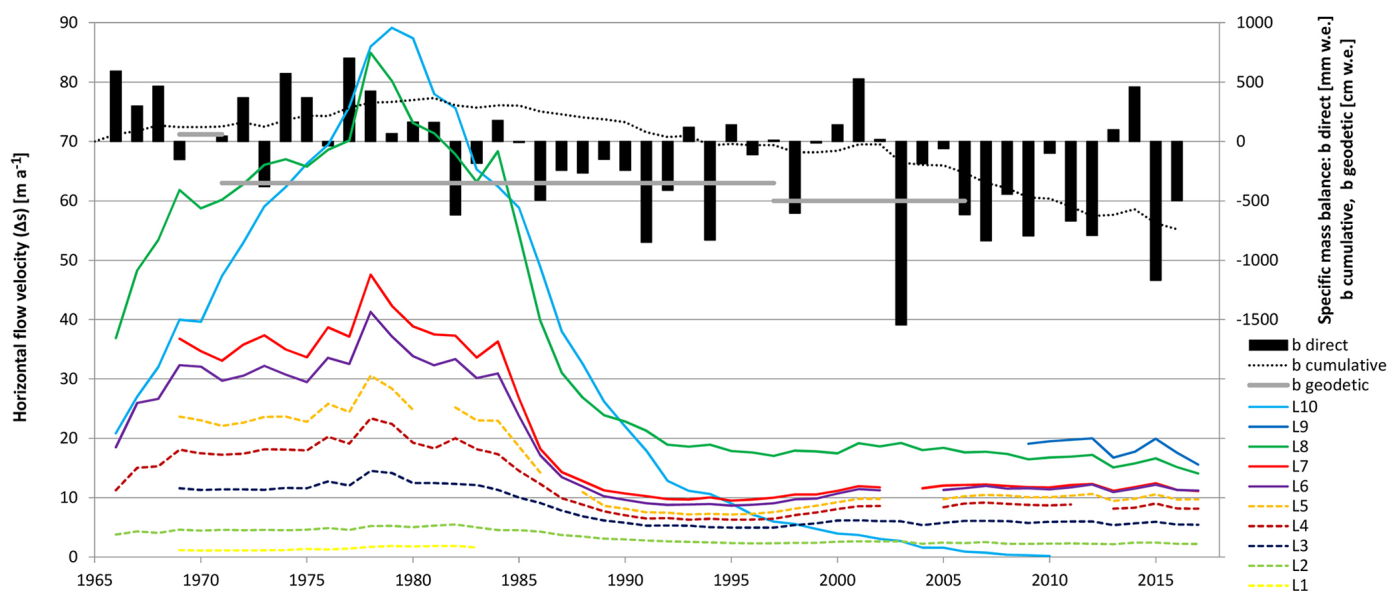

Figure 4. Annual horizontal flow velocities $(\Delta s / a)$ at the accumulation and ablation stakes on Kesselwandferner (e.g. the year 2015 refers to the hydrological year 2014/2015) and the specific surface mass balance (b direct) (Strasser et al., 2018; WGMS, 2017), as well as the geodetic balances from DODs (b geodetic) by Fischer (2011). Locations of the stakes are shown in Fig. 1.

\subsection{Gepatschferner and Taschachferner}

The measurements of ice flow velocities and ablation on GPF and TSF were started in 2009/10. The stake network on GPF was extended in 2012. During these measurements, interannual velocity fluctuations were small, especially at the three stakes on TSF (54, 55 and 56). At the lowermost Stake 54, the horizontal velocities were less than $10 \mathrm{~m}$ per year during the whole period. The two higher-altitude points 55 and 56 returned velocities of 30 to around $40 \mathrm{~m}$ per year. The higher values at 55 compared to 56 are caused by topographic effects, with a steepening of the glacier tongue and a narrowing of the cross section from Stake 56 towards Stake 55 (Fig. 6).

On GPF, a general trend of decreasing surface velocities was found at all stakes, with a larger decline in velocity at the terminus than at the upper cross-profile (71-75). At Stake 62, a funnel-shaped surface depression, caused by an evacuation of subglacial sediments due to a heavy precipitation event, led to a spatially limited increase in surface velocity in that area and a later decrease to almost zero (Stocker-Waldhuber et al., 2017). In total, a general slowdown of velocities at the tongue of GPF was found since the beginning of the measurements.

An example of sub-seasonal fluctuations in surface velocity is given in Fig. 7 for Stake 65 at GPF, which has been measured from 2009 with the least data gaps since then. The velocities are given as mean values per day to make the different time periods of the stake readings comparable. During the winter seasons velocities generally decrease. Maximum values were typically found in August each year, except for the years 2013 and 2014, which had earlier peaks in July. During winter months the elevation change of the surface from geodetic measurements is close to zero or even positive while surface velocity is decreasing. The opposite process is found during the summer season, when the highest surface velocities go along with the most negative elevation change. 


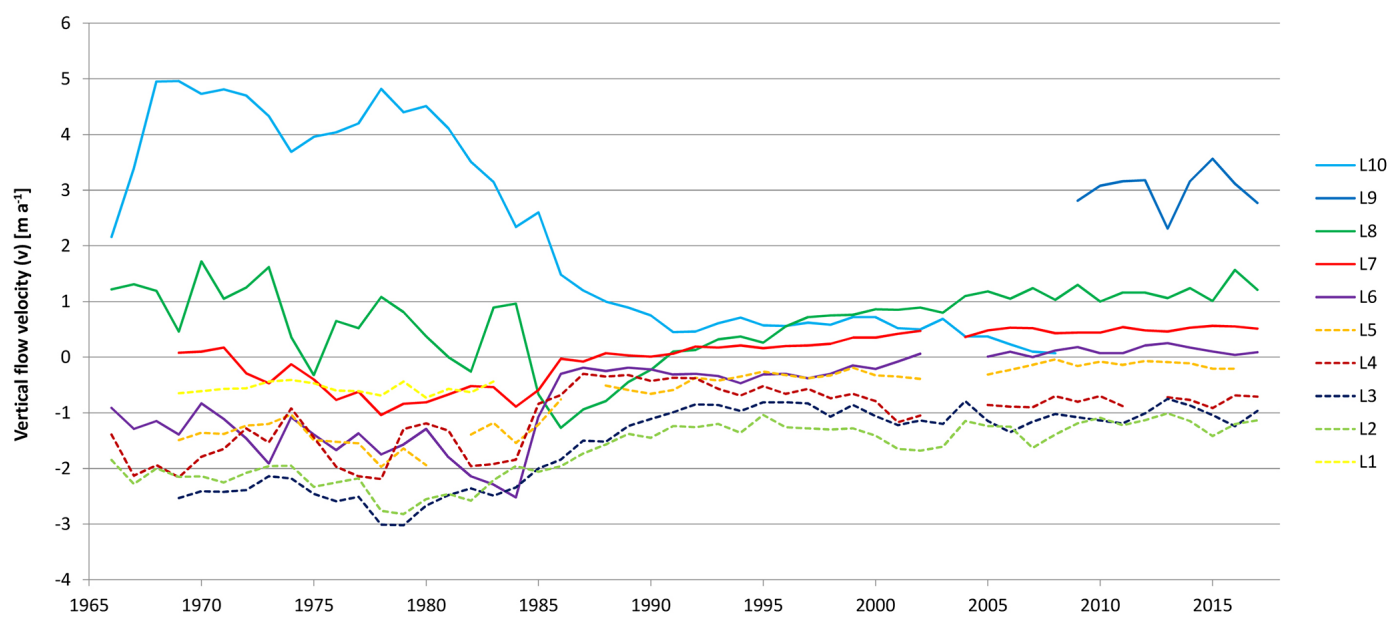

Figure 5. Annual vertical velocities $(\Delta v / a)$ at the accumulation and ablation stakes on Kesselwandferner (e.g. the year 2015 refers to the hydrological year 2014/2015). Positive values represent emergence flow, negative ones represent submergence flow. Locations of the stakes are shown in Fig. 1.

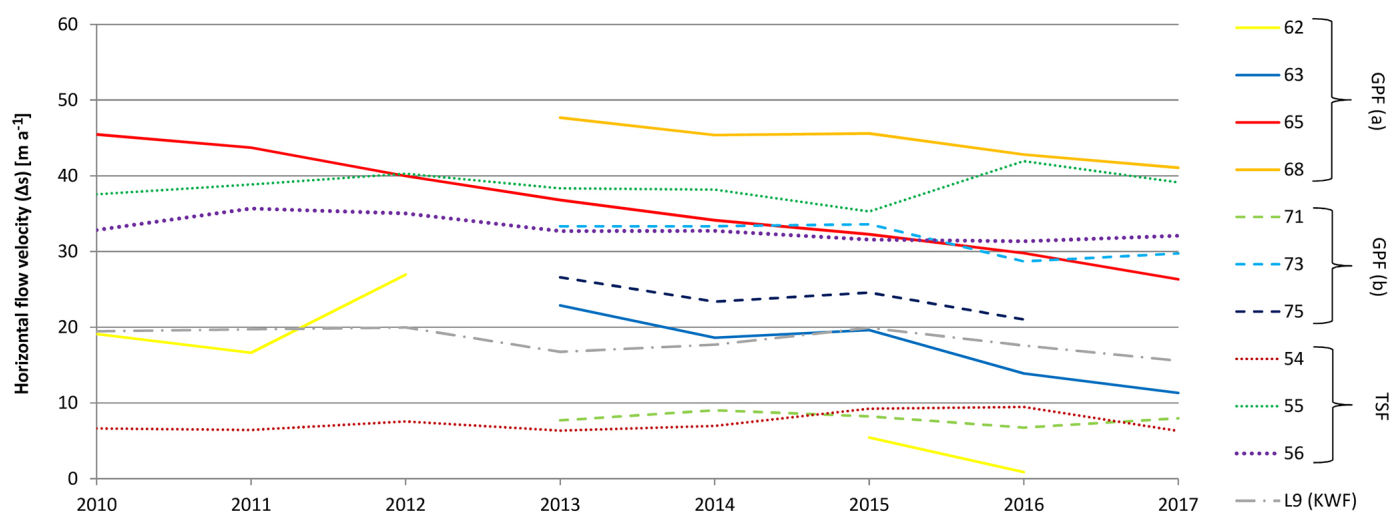

Figure 6. Annual horizontal flow velocities $(\Delta s / a)$ on Gepatschferner and Taschachferner and L9 at Kesselwandferner for comparison (e.g. the year 2015 refers to the hydrological year 2014/2015). GPF (a): selection of the longitudinal stakes at the tongue of Gepatschferner. GPF (b): three stakes at the cross-profile. Locations of the stakes are shown in Fig. 1: Stake 71 - orogr. left side; Stake 73 - centre; Stake 75 - orogr. right side.

\section{Discussion}

The investigations show that the magnitude of the fluctuations of the surface velocities is higher at the ablation stakes compared to those within the accumulation area and highest at the lowermost stakes. This means that changes in observed velocity, especially at ablation stakes, are very well suited for documenting the glacier state, even more so at a fast reacting glacier like KWF. This is supported by a linear regression of annual mean specific balance (b) of the total glacier area of HEF and KWF versus the mean specific balance of their accumulation areas (bc) for the period 1965/661999/00 by Span and Kuhn (2003). They found nearly identical correlation coefficients for the two balances, while the standard deviation $\sigma(\mathrm{b})$ was twice as high as $\sigma(\mathrm{bc})$, documenting the higher sensitivity of the ablation areas to mass balance changes of the two glaciers.
On GPF and TSF these measurements were conducted exclusively at stakes at the tongue where the decreasing velocity rates represent the retreating state of the glacier. The decreasing velocities were found especially on GPF, in contrast to TSF, where the flow rates remained almost constant during these investigations. This is caused by the specific topographic conditions of the TSF glacier tongue, which is steeper and shorter, and the terminus is located at a higher altitude compared to the tongue of GPF.

The sub-seasonal fluctuations on GPF (Fig. 7) represent the typical acceleration of the glacier during summer months, which is well known and was, for example, already measured on HEF between the end of July and mid-September from 1900 to 1904 by Blümcke and Finsterwalder (1905). The summer peaks on GPF and TSF were found mainly during August each year. These sub-seasonal fluctuations depend on the drainage network, which is driven by the amount of 


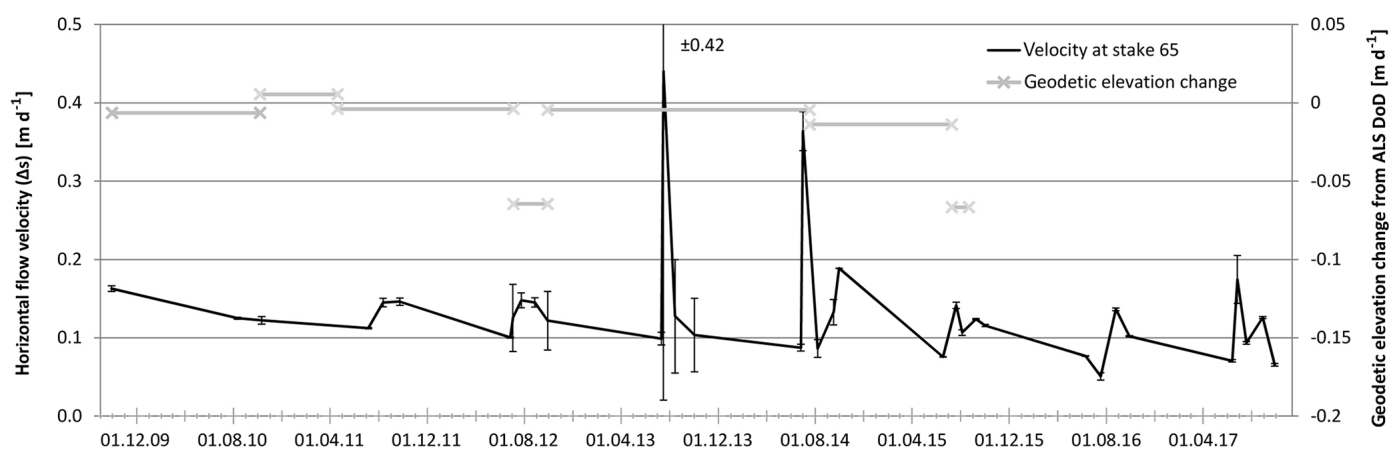

Figure 7. Mean daily horizontal velocities $\left(\Delta s \mathrm{~d}^{-1}\right)$ at Stake 65 on Gepatschferner between the measurements, as an example of the subseasonal fluctuation of surface velocity. The peak in July 2013 shows the highest uncertainty, very likely because of few satellites due to shading effects of the surrounding topography, which depend on the time of the measurements. Additional information is given by the mean elevation change per day from ALS DODs at the position of the stake (data extended from Stocker-Waldhuber et al., 2017).

melt water, seasonal and extreme weather conditions (Iken, 1977; Gudmundsson, 2002). The accuracy of the measurements on GPF varies over time and depends on shading effects of the surrounding topography. For example, the peak in 2013 shows the greatest uncertainty due to topographic shading effects and is thus not representative of the actual surface velocity.

Generally, the glacier surface velocities will be overestimated by stone velocity measurements, especially at low velocities and high ablation rates. This difference is shown by Hess (1924) for the period between 1913/14 and 1921/22 with measured surface velocities at neighbouring stones and boreholes.

\section{Data availability}

Velocity data of the four glaciers Hintereisferner, Kesselwandferner, Gepatscherner and Taschachferner are available at https://doi.org/10.1594/PANGAEA.896741 (StockerWaldhuber et al., 2018). New data will be added every year.

\section{Conclusions}

The long-term investigations of the surface velocities at these glaciers document the state of each glacier and its response to a climate signal. Three periods with accelerating velocities caused by positive mass balances were found in the longest time series on HEF. A time shift of the maximum values from higher to lower stone line profiles indicates the response time of the tongue. Despite the increase in surface velocities during these three periods, mass gain on HEF was insufficient for the terminus to advance, except for a small advance during the 1920s. The 1920s peak velocity at Line 3 was also confirmed by measurements at boreholes, stakes and additional stones within the ablation area (Hess, 1924). In contrast to HEF, the terminus of KWF advanced by more than $250 \mathrm{~m}$ from the 1970s to the 1980s (Patzelt, 1985; Fis- cher et al., 2018). KWF presents an immediate response at all profiles concurrently, which means that a mass gain or increase in the thickness within the accumulation area causes an increase in the emergence at the lowermost stakes within 1 year.

During glacier retreat, the transition from submergence to emergence shifts to higher elevations, as was found on KWF from 1986 to the present. As a consequence, the magnitude of the vertical velocities decreases, which leads to increasing retreat rates of the terminus but, at the same time, to an increase in the thickness at higher elevations in case of a positive mass balance. Apart from the effect of the mass balance, according to the continuity equation, local thickness changes can also be caused by convergent or divergent glacier flow.

For the investigated temperate mountain glaciers, ice flow velocity is a glaciological parameter that reacts very quickly to changes in the forcing such as the glacier mass balance variability (Huss, 2012). As conventional parameters like ELA tend to be above the summit for the investigated glaciers under current conditions and specific mass balance is affected by rapid changes in area, long-term monitoring of ice flow provides valuable additional information on the glacier state. Our dataset allows for the development and validation of perspectives on ice flow velocity as monitoring tool.

Author contributions. MSW is responsible for the velocity measurements and data analyses of Hintereisferner, Kesselwandferner and Gepatschferner, prepared the figures and wrote the manuscript. $\mathrm{AF}$ is leading the working group, accounts for the maintenance of the long-term monitoring programs and contributed in writing the manuscript. $\mathrm{KH}$ is responsible for the velocity measurements and data analyses of Taschachferner. MK initiated the measurements on Gepatschferner and Taschachferner. All co-authors were involved in corrections and additions to the manuscript during the whole review process. 
Competing interests. The authors declare that they have no conflict of interest.

Acknowledgements. Maintaining long-term monitoring is always a challenging task and requires financial support and the help of numerous people, to whom we would like to gratefully express our thanks. Terminus variations of the glaciers and the velocity records on HEF relate to the annual measurements of the Austrian Alpine Club. Mass balance terms are provided by the World Glacier Monitoring Service (WGMS) and the Institute of Atmospheric and Cryospheric Sciences (ACINN). Research (project PROSA) on GPF was funded by DFG (SCHM 472/16-1, SCHM 472/17-2 and BE 1118/33-3) and FWF (I 894-N24 and I 1646N19) and funding continues from the glacier ski resort Kaunertaler Gletscher GmbH and Tiroler Wasserkraft AG (TIWAG), which also support the measurements on TSF. We want to thank Heralt Schneider who started the velocity records on KWF and continued them for more than 50 years. These records are now supported by the nonprofit organization Glacier and Climate. We want to thank Brigitte Scott for editing the English. We thank Reinhard Drews (Ed.) and the reviewers Mauri Pelto and Andreas Bauder, who gave us useful comments that helped us to improve this paper.

Financial support. This research has been supported by the Deutsche Forschungsgemeinschaft (grant no. BE 1118/33-3) and the Österreichische Forschungsförderungsgesellschaft (grant no. I 1646-N19).

Review statement. This paper was edited by Reinhard Drews and reviewed by Mauri Pelto and Andreas Bauder.

\section{References}

Abermann, J., Fischer, A., Lambrecht, A., and Geist, T.: On the potential of very high-resolution repeat DEMs in glacial and periglacial environments, The Cryosphere, 4, 53-65, https://doi.org/10.5194/tc-4-53-2010, 2010.

Agassiz, L.: Système glaciaire ou recherches sur les glaciers, leur mécanisme, leur ancienne extension et le rôle qu'ils ont joué dans l'histoire de la terre. Première partie: Nouvelles études et expériences sur les glaciers actuels, leur structure, leur progression et leur action physique sur le sol, V. Masson, Paris, 1847.

Berthier, E. and Vincent, C.: Relative contribution of surface massbalance and ice-flux changes to the accelerated thinning of Mer de Glace, French Alps, over 1979-2008, J. Glaciol., 58/209, 501512, https://doi.org/10.3189/2012JoG11J083, 2012.

Blümcke, A. and Finsterwalder, S.: Zeitliche Änderung der Geschwindigkeit in der Gletscherbewegung, Sitzungsbericht der math.-phys. Kl. der Kgl. Bayer, Akademie der Wissenschaften, Bd.35/1, 109-131, in: Z. Gletscherk., 1, 73-75, 1905.

Blümcke, A. and Hess, H.: Untersuchungen am Hintereisferner. Wissenschaftliche Ergänzungshefte zur Zeitschrift des DeutschÖsterreichischen Alpenvereins, 1, 1-87, 1899.
Braun, L., Reinwarth, O., and Weber, M.: Der Vernagtferner als Objekt der Gletscherforschung, Z. Gletscherk. Glazialgeol., 45/46, 85-104, 2012

Cogley, J. G., Hock, R., Rasmussen, L. A., Arendt, A. A., Bauder, A., Braithwaite, R. J., Jansson, P., Kaser, G., Möller, M., Nicholson, L., and Zemp, M.: Glossary of Glacier Mass Balance and Related Terms, IHP-VII Technicl Documents in Hydrology, No. 86, IACS Contribution No. 2, UNESCO-IHP, Paris, 2011.

Cuffey, K. M. and Paterson, W. S. B.: The Physics of Glaciers, Academic Press, Amsterdam, 4th Ed., 704 pp., 2010.

Finsterwalder, S.: Die Theorie der Gletscherschwankungen, Z. Gletscherk. Glazialgeol., 1, 81-103, 1907.

Finsterwalder, S.: Begleitworte zur Karte des Gepatschferners, Z. Gletscherk., 16, 20-41, 1928.

Fischer, A.: Glaciers and climate change: Interpretation of 50 years of direct mass balance of Hintereisferner, Global Planet. Change, 71, 13-26, https://doi.org/10.1016/j.gloplacha.2009.11.014, 2010.

Fischer, A.: Comparison of direct and geodetic mass balances on a multi-annual time scale, The Cryosphere, 5, 107-124, https://doi.org/10.5194/tc-5-107-2011, 2011.

Fischer, A., Markl, G., and Kuhn, M.: Glacier mass balance and elevation zones of Hintereisferner, Ötztal Alps, Austria, 1952/1953 to 2010/2011, PANGAEA, https://doi.org/10.1594/PANGAEA.818898, 2013.

Fischer, A., Markl, G., Schneider, H., Abermann, J., and Kuhn, M.: Glacier mass balances and elevation zones of Kesselwandferner, Ötztal Alps, Austria, 1952/1953 to 2012/2013, PANGAEA, https://doi.org/10.1594/PANGAEA.818757, 2014.

Fischer, A., Patzelt, G., Achrainer, M., Groß, G., Lieb, G., and Keller-Pirkelbauer-Eulenstein, A.: Gletscher im Wandel, 125 Jahre Gletschermessdienst des Alpenvereins. Springer Spektrum, 135 pp., 2018.

Fischer, A., Seiser, B., Stocker-Waldhuber, M., Mitterer, C., and Abermann, J.: Tracing glacier changes in Austria from the Little Ice Age to the present using a lidar-based high-resolution glacier inventory in Austria, The Cryosphere, 9, 753-766, https://doi.org/10.5194/tc-9-753-2015, 2015.

Forbes, J. D.: Illustrations of the viscous theory of glacier motion, Philos. Trans. Roy. Soc., 136, 143-210, 1846.

Förtsch, O. and Vidal, H.: Die Ergebnisse seismischer Messungen auf dem Hintereisferner in den Ötztaler Alpen 1954, Gerlands Beiträge zur Geophysik, 65, 131-156, 1956.

Fritzsch, M.: Verzeichnis der bis Sommer 1896 in den Ostalpen gesetzten Gletschermarken, Verlag des Deutschen und Österreichischen Alpenvereins, Wien, 1898

Giese, P.: Some results of seismic refraction work at Gepatsch Glacier in the Ötztal Alps, IAHS Publications, 61, 154-161, 1963.

Groß, G.: Der Flächenverlust der Gletscher in Österreich 1850 1920-1969, Z. Gletscherk. Glazialgeol., 23/2, 131-141, 1987.

Groß, G.: Die Geschichte der Gletscherbeobachtungen und messungen in den Österreichischen Alpen, Kapitel 5, in: Gletscher im Wandel, 125 Jahre Gletschermessdienst des Alpenvereins, edited by: Fischer, A., Patzelt, G., Achrainer, M., Groß, G., Lieb, G., Kellerer-Pirklbauer-Eulenstein, A., and Bendler, G., Springer Spektrum, 53-93, 2018.

Gudmundsson, H.: Observations of a reversal in vertical and horizontal strain-rate regime during a motion event on Unteraar- 
gletscher, Bernese Alps, Switzerland, J. Glaciol., 48, 566-574, 2002.

Hays, J. D., Imbrie, J., and Shackleton, N. J.: Variations in the Earth's Orbit: Pacemaker of the Ice Ages, Science, 194, 11211132, 1976.

Heckmann, T. and Morche, D. (Eds): Geomorphology of Proglacial Systems - Landform and Sediment Dynamics in Recently Deglaciated Alpine Landscapes, Springer International Publishing, Basel, 2019.

Heckmann, T., Haas, F., Morche, D., Schmidt, K. H., Rohn, J., Moser, M., Leopold, M., Kuhn, M., Briese, C., Pfeiffer, N., and Becht, M.: Investigating an Alpine proglacial sediment budget using field measurements, airborne and terrestrial LiDAR data, IAHS Press, Wallingfort IAHS Publication 356, 438-447, 2012.

Heim, A.: Handbuch der Gletscherkunde, Verlag von J. Engelhorn, Stuttgard, 560 pp., 1885.

Helfricht, K., Kuhn, M., Keuschnig, M., and Heilig, A.: Lidar snow cover studies on glaciers in the Ötztal Alps (Austria): comparison with snow depths calculated from GPR measurements, The Cryosphere, 8, 41-57, https://doi.org/10.5194/tc-8-41-2014, 2014.

Hess, H.: Die Gletscher, F. Vieweg und Sohn, Braunschweig, 426 pp., 1904.

Hess, H.: Der Hintereisferner 1893 bis 1922, Ein Beitrag zur Lösung des Problems der Gletscherbewegung, Z. Gletscherk., 13, 145-203, 1924.

Hoinkes, H.: Methoden und Möglichkeiten von Massenhaushaltsstudien auf Gletschern, Z. Gletscherk. Glazialgeol., 6, 37-90, 1970.

Hoinkes, H. and Steinacker, R.: Hydrometeorological implications of the mass balance of Hintereisferner, 1952-53 to 1968-69, Snow and Ice Symposium-Neiges et Glaces (Proceedings of the Moscow Symposium, August 1971), IAHS-AISH Publ., 104, 1975.

Huss, M.: Extrapolating glacier mass balance to the mountain-range scale: the European Alps 1900-2100, The Cryosphere, 6, 713727, https://doi.org/10.5194/tc-6-713-2012, 2012.

Iken, A.: Variations of surface velocities of some Aline glaciers measured at intervals of a few hours. Comparison with Arctic glaciers, Z. Gletscherk. Glazialgeol., 13, 23-35, 1977.

Jacob, T., Wahr, J., Pfeffer, W. T., and Swenson, S.: Recent contributions of glaciers and ice caps to sea level rise, Nature, 482, 514, https://doi.org/10.1038/nature10847, 2012.

Keutterling, A. and Thomas, A.: Monitoring glacier elevation and volume change with digital photogrammetry and GIS at Gepatschferner glacier, Austria, Int. J. Remote Sens., 27/19, 4371-4380. https://doi.org/10.1080/01431160600851819, 2006.

Kuhn, M., Kaser, G., Markl, G., Nickus, U., and Pellet, F.: Fluctuations of climate and mass balance: Different responses of two adjacent glaciers, Z. Gletscherk. Glazialgeol., 21, 409-416, 1985.

Kuhn, M., Dreiseitl, E., Hofinger, S., Markl, G., Span, N., and Kaser, G.: Measurements and Models of the Mass Balance of Hintereisferner, Geograf. Annal., 81, 659-670, 1999.

Kuhn, M., Lambrecht, A., Abermann, J., Patzelt, G., and Groß, G.: The Austrian glaciers 1998 and 1969, area and volume changes, Z. Gletscherk. Glazialgeol., 43, 3-107, 2012.

Mercanton, P. L.: Vermessungen am Rhonegletscher. Mensurations au glacier du Rhone 1874-1915, Gletscher-Kommission der Schweizerischen Naturforschenden Gesellschaft, Band LII,
Vol. LII, Kommissions-Verlag Georg \& Co, Basel, Genf, Lyon, 191 pp., 1916.

Milankovitch, M.: Théorie Mathématique des Phénomènes Produits par la Radiation Solaire, Gauthier-Villars, Paris, 1920.

Nicolussi, K.: Die historischen Vorstöße und Hochstände des Vernagtferners 1600-1850 AD, Z. Gletscherk. Glazialgeol., 45/46, 9-23, 2012.

Nicolussi, K. and Patzelt, G.: Untersuchungen zur holozänen Gletscherentwickung von Pasterze und Gepatschferner (Ostalpen), Z. Gletscherk. Glazialgeol., 36, 1-87, 2001.

Niederwald, T.: Festpunktbestimmung mit GPS für GletscherMonitoring-Projekte in den Ötztaler Alpen (Tirol), Master thesis, Hochschule für Angewandte Wissenschaften FH München, Fakultät für Geoinformation, 2009.

Patzelt, G.: The Austrian Glacier Inventory: Status and First Results, IAHS Publication, 126, 181-183, 1980.

Patzelt, G.: The period of glacier advances in the Alps, 1965 to 1980, Z. Gletscherk. Glazialgeol., 21, 403-407, 1985.

Penck, A. and Brückner, E.: Die Alpen im Eiszeitalter, Tauchnitz, Leipzig, 1909.

Roethlisberger, H.: The Rhone glacier surveys, Hydrol. Sci. J., 8, 119-121, https://doi.org/10.1080/02626666309493319, 1963.

Schneider, H.: Die Grundlagen der Vermessung am Kesselwandferner (Ötztaler Alpen) und die Bewegung dieses Gletschers in den Haushaltsjahren 1965/66, 1966/67 und 1967/68, Dissertation an der philosophischen Fakultät der Universität Innsbruck, 186 pp., 1970.

Shackleton, N. J.: The 100,000-Year Ice-Age Cycle Identified and Found to Lag Temperature, Carbon Dioxide, and Oribtal Eccentricity, Science, 289, 1897-1902, 2000.

Sonklar, K.: Die Oetzthaler Gebirgsgruppe mit besonderer Rücksicht auf Orographie und Gletscherkunde, Justus Perthes, Gotha, 1860.

Span, N. and Kuhn, M.: Simulating annual glacier flow with a linear reservoir model, J. Geophys. Res., 108, 4313, https://doi.org/10.1029/2002JD002828, 2003.

Span, N., Kuhn, M., and Schneider, H.: 100 years of ice dynamics of Hintereisferner, Central Alps, Austria, 1884-1994, Ann. Glaciol., 24, 297-302, https://doi.org/10.1017/S0260305500012349, 1997.

Stocker-Waldhuber, M., Fischer, A., Keller, L., Morche, D., and Kuhn, M.: Funnel-shaped surface depressions - Indicator or accelerant of rapid glacier disintegration? A case study in the Tyrolean Alps, Geomorphology, 287, 58-72, https://doi.org/10.1016/j.geomorph.2016.11.006, 2017.

Stocker-Waldhuber, M., Fischer, A., Helfricht, K., Kuhn, M., Schneider, H., and Span, N.: Glacier surface velocities in the Ötztal Alps (Austria), PANGAEA, https://doi.org/10.1594/PANGAEA.896741, 2018.

Strasser, U., Marke, T., Braun, L., Escher-Vetter, H., Juen, I., Kuhn, M., Maussion, F., Mayer, C., Nicholson, L., Niedertscheider, K., Sailer, R., Stötter, J., Weber, M., and Kaser, G.: The Rofental: a high Alpine research basin (1890-3770 m a.s.1.) in the Ötztal Alps (Austria) with over 150 years of hydrometeorological and glaciological observations, Earth Syst. Sci. Data, 10, 151-171, https://doi.org/10.5194/essd-10-151-2018, 2018.

Weide, S.: Estimating the Height Accuracy of Airborne Laser Scanning with GPS and Calculation of Glacier Movement at Hin- 
tereisferner, Master thesis, Hochschule für Angewandte Wissenschaften FH München, Fakultät für Geoinformation, 2009.

WGMS: Global Glacier Change Bulletin No. 2 (2014-2015), edited by: Zemp, M., Nussbaumer, S. U., Gärtner-Roer, I., Huber, J., Machguth, H., Paul, F., and Hoelzle, M., ICSU(WDS)/IUGG(IACS)/UNEP/UNESCO/WMO, World Glacier Monitoring Service, Zurich, Switzerland, 244 pp., publication based on database version: https://doi.org/10.5904/wgmsfog-2017-10, 2017.

Zauner, R.: Glaziologische Analyse der Gletscheroberfläche am Blockgletscher Äußeres Hochebenkar, Hintereisferner und am Kesselwandferner (Ötztaler Alpen), Bachelor thesis, Hochschule für Angewandte Wissenschaften FH München, Fakultät für Geoinformation, 2010.
Zemp, M., Huss, M., Thibert, E., Eckert, N., McNabb, R., Huber, J., Barandun, M., Machguth, H., Nussbaumer, S.U., Gärtner Roer, I., Thomson, L., Paul, F., Maussion, F., Kutuzov, S., and Cogley, J. G.: Global glacier mass changes and their contributions to sea-level rise from 1961 to 2016, Nature, 568, 382-386, https://doi.org/10.1038/s41586-019-1071-0, 2019. 